\title{
WELVAART
}

\section{BENTUK INTERVENSI GURU BIMBINGAN DAN KONSELING DALAM MENANGANI SISWA BERMASALAH (Studi di SMA Negeri 1 Gu Kabupaten Buton Tengah)}

Wa Aisa, La Ode Monto Bauto, Megawati Asrul Tawulo

Fakultas Ilmu Sosial dan Ilmu Pilitik Universitas Halu Oleo

Email: aisakesos510@gmail.com, laodemonto@yahoo.co.id, megawatiasrultawulo@gmail.com

Korespondensi: Megawati Asrul Tawulo

Email: megawatiasrultawulo@gmail.com

\begin{abstract}
ABSTRAK
Penelitian Ini Bertujuan Untuk Mengetahui Faktor Penyebab Siswa Yang Bermasalah Di SMA Negeri $1 \mathrm{Gu}$ Kabupaten Buton Tengah Dan Untuk Mengetahui Bentuk Intervensi Guru Bimbingan Dan Konseling Dalam Menangani Siswa Bermasalah Di SMA Negeri 1 Gu Kabupaten Buton Tengah. Jenis penelitian ini adalah penelitian deskripstif kualitatif. Teknik pengumpulan data dilakukan dengan cara observasi,wawancara, dan dokumentasi dengan informan sebanyak 12 orang Hasil penelitian ini menunjukan bahwa faktor yang menyebabkan siswa bermasalah di Sekolah SMA Negeri 1 Gu Kabupaten Buton Tengah yaitu faktor internal dan faktor eksternal. faktor internal yaitu (1) sikap terhadap belajar siswa (2) motivasi belajar siswa.(3) kosentrasi belajar,(4)kemampuan berprestasi. (5) rasa percaya diri siswa sangat minim terutama dalam menjawab pertanyaan yang diberikan oleh guru. faktor ekternal yaitu: (1) keluarga broken home, kebanyakan dari siswa yang bermasalah disebabkan oleh keluarga yang tidak harmonis lagi, yang dimana siswa masih membutuhkan kasih sayang dan perhatian dari kedua orang tuanya. (2) rendahnya tingkat pendidikan orang tua, (3) Lingkung Sosial. (4) Bentuk Intervensi Guru Bimbingan Dan Konseling Dalam Menangani Siswa Bermasala yaitu dengan melakukan konseling individu dan konseling kelompok yang dilakukan oleh guru bimbingan kornseling dalam penyelesaian masalah dimana guru BK melihat permasalahan siswa yang sama dan dikumpulkan dalam satu ruangan untuk menyelesaikan permasalahan yang mereka hadapi dengan pemberian motivasi terhadap siswa.
\end{abstract}

Kata Kunci: Intervensi, Guru Bimbingan dan Konseling, Siswa Bermasalah

\section{PENDAHULUAN}

Pendidikan adalah salah satu alat yang digunakan membentuk manusia yang berkepribadian dan berkesadaran. Pendidikan dan manusia adalah suatu kesatuan yang utuh yang tak dapat terpisahkan dalam kaitannya dengan proses pengembangan diri. Manusia tentunya tidak akan terlepas dari kebutuhan akan pengetahuan belajar dan bagaimana pendidikan itu mampu menjadi penompang 


\section{WELVAART}

dalam membuat manusia mengetahuai keberadaan dirinya sebagai manusia mandiri. Pendidikan dalam perkembangan menuntut adanya suatu organisasi yang mandiri untuk melahirkan manusia-manusia yang unggul dan berkarakter demi tercapainya hakikat dari pendidikan itu sendiri (Irwansa, 2015).

Alwi (2018) mejelaskan bahwa dalam proses pendidikan di sekolah ,kehidupan siswa sangat dinamis dan berada dalam proses perkembangan, memiliki kebutuhan dan dinamika dalam interaksinya dengan lingkunganya. Proses perkembngan di pengaruhi oleh beberapa factor baik dalam maupun luar. Bimbingan dan konseling ( BK) merupakan salah satu unsur dari pendidikan yang harus ada disekolah pada umumnya dan untuk meningkatkan mutu pendidikan yang ada di sekolah pada khususnya.

Undang -Undang SISDIKNAS Nomor 20 Tahun 2003 tentang Sistem Pendikakan menjelaskan, bahwa tujuan pendidikan adalah usaha sadar dan terencana untuk mewujudkan suasana belajar dan proses pembelajaran agar peserta didik secara aktif mengembangkan potensi dirinya untuk memiliki kekuatan spiritual, keagamaan, pengendalian diri,kepribadian, kecerdasan, akhalak mulia, serta keterampilan yang dilakukan dirinya, masyarakat maupun bangsa dan Negara.

Bimbangan dan konseling merupakan proses pemberian bantuan yang diberikan kepada individu-individu dalam upaya membantu indivudu dalam mencapai tugas-tugas perkembangan sehingga dapat tercapai tuga-tugas perkembangananya sehingga dapat tercapaia perkembangan yang optimal (Prayitno dan Emran, Amti, 2004).

SMA Negeri 1 GU merupakan salah satu sekolah yang terletak di Kelurahan Watulea Kecamatan Gu Kabupaten Buton Tengah. Sekolah yang terbilang umur pendirinya cukup tua, jumlah guru-guru yang menjagajar lumayan banyak, dan jumlah siswanya lumayan banyak juga dan lokasi sekolahnya sangat strategis berada di tengah-tengah pemukiman masyarakat. Tujuan pembangunan sekolah ini adalah di samping pemerataan lembaga pendidikan di setiap pelosok juga mengurangi biaya transportasi bagi siswa yang kurang mampu. Namun 


\section{WELVAART}

pembangunan sekolah ini tidak di manfaatkan dengan baik oleh siswa, dimana banyak terdapat siswa yang bermasalah dalam bertingkah laku tidak selama mengarah kepada apa yang di harapkan oleh sekolah melainkan adanya pelanggaran tata tertib yang dilakukan kukan oleh siswa. Oleh karena itu seorang guru harus mampu melakukan pengawasan dan mengembalikan siswa yang bermasalah menjadi perilaku yang taat dan tertib aturan. Karena tugasnya guru bukan hanya senantiasa mengajarkan mata pelajaran kepada siswa tetapi juga mampu bagaimana membimbing perilaku siswa sesuai dengan aturan yang ada sehingga siswa menjadi pribadi yang baik, cerdas ,patuh dan disiplin. Sampai saat ini siswa SMA Negeri $1 \mathrm{Gu}$ Kabupaten Buton Tengah jumlah siswanya yang ada di sekolah tersebut, 567 siswa dan terbagi atas 2 kelas yaitu kelas IPA dan kelas IPS. Di sekolah tersebut siswa banyak menimbulkan masalah dan masalah pada siswa sangatlah beragam.

\section{METODE}

Jenis penelitian yang dilakukan oleh penulis adalah penelitian deskriptif Kualitatif. Jenis penelitian ini untuk memberikan gambaran atau penjelasan secara detail mengenai Bentuk Intervensi Guru Bimbingan dan Konseling, dalam Menangani Siswa Bermasalah di sekolah SMA Negeri 1 Gu Kabupaten Buton Tengah. Informan penelitian ini adalah terdiri dari kepala sekolah, siswa, Guru BK dan guru-gurunya yang ada di sekolah SMA Negeri 1 Gu Kabuapten Buton Tengah yang berjumla 12 orang informan. Adapun pemilihan inforaman dilakukan dengan teknik purposive sampling penunjukan langsung kepada subjek yang dianggap memiliki pengetahuan tentang permasalahan yang akan diteliti yaitu Bentuk Intervensi Guru Bimbingan dan Konseling, dalam Menangani Siswa Bermasalah di sekolah SMA Negeri 1 Gu Kabupaten Buton Tengah.

\section{HASIL DAN PEMBAHASAN}

\section{Faktor Penyebab Kenakalan Siswa}

a. Faktor Internal

1. Sikap Terhadap Belajar Siswa

Selama melakukan proses pembelajaran sikap Siswa akan menemukan hasil dari pembelajaran tersebut. Pemahaman Siswa yang salah terhadap belajar 


\section{WELVAART}

akan membawa kepada sikap yang salah dalam melakukan pembelajaran. Sikap Siwa ini akan mempengaruhinya terhadapan tindakan belajar. Sikap yang salah akan membawa Siswa merasa tidak peduli dengan belajar lagi. Akibatnya tidak akan terjadi proses belajar yang kondusif. Sebagimana yang di ungkapkan oleh Pak La Huri Selaku Guru BK.

Sepantuan saya kebanyakan siswa disini itu sikap dan perilaku mereka yang kurang beretika, kurang sopan sekali, baik sesama Siswa maupun sama Gurunya. Karena memang anak-anak disini sikap dan perilaku mereka terkontaminasi atau sangat menyatu dengan lingakungan rumah yang kurang baik,akhirnya sikap dan perilaku mereka terbawa sampai dilingkungan Sekolah"(Selasa 02 Februari 2021)

Berdasrkan wawancara diatas dapat diketahui bahwa sikap dan perilaku

Siswa di Sekolah SMA Negeri 1 Gu Kabupaten Buton Tengah kurang beretika dan kurang sopan baik ama teman-temannya maupun dengan Gurunya. Hal ini disebabkan oleh lingkungan tempat tinggal mereka kurang baik. Karena pada dasarnya lingkungan adalah salah satu faktor yang menentukan baik buruknya seseorang dalam bergaul, dengan lingkungan yang tidak baik maka dapat mempengaruhi sikap dan perilaku anak.

2. Motivasi Belajar

Motivasi belajar merupakan kekuatan mental yang mendorong terjadinya proses belajar, dan sebaliknya dengan lemahnya motivasi belajar akan mempengaruhi kegiatan belajar yang dapat menimbulkan rasa malas dalam beraktivitas, sebagai anak yang menempuh pendidikan dapat dilihat dengan kurangnya perhatian kepada Guru, malas belajar, dan juga malas mengerjakan PR dari Guru. Hal ini sesuai dengan yang diungkapkan oleh Ibu Wa Saiyah selaku Guru di Sekolah SMA Negeri 1 Gu Kabupaten Buton Tengah. Berikut penuturanya saat proses wawancara berlangsung:

Kebanyakan Siswa Siswa disini sangat kurang dalam minat mereka untuk membaca buku mata pelajaran yang diberikan dari Sekolah, dan mengumpulkan PR itu mereka jarang, namun sebagian juga Siswa memperhatikan tugas rumahnya yang diberikan oleh Guru- gurunya mata pelajaran yang bersangkutan, dan kadang-kadang juga Siswa yang malas klw 


\section{WELVAART}

mereka mengerjakan PR itu asal jadi atau seleseai." (Kamis,04 Februari 2021)

Dari hasil wawancara di atas dapat diketahui bahwa dalam proses belajar Siswa di Sekolah terutama dalam motifasi membaca, minat Siswa dalam membaca buku di Sekolah sangat kurang, padahal dengan banyak membaca buku dapat menambah wawasan pengetahuan, dan banyak hal yang dapat ditemukan dalam bacaan tersebut, dengan membaca pula orang bisa sukses dengan baik dan bisa membuka kunci dunia. Selain motifasi kurangnya membaca, Siswa yang ada di Sekolah SMA Negeri 1 Gu Kabupaten Buton Tengah, juga jarang dalam mengerjakan tugas rumah (PR) yang diberikan oleh Guru-guru mata pelajaran yang bersangkutan, padahal dengan diberikannya tugas dapat mengasah kembali ingatan Siswa mengenai mata pelajaran yang telah didapatkan dari Guru di Sekolah. Namun mereka tidak memperhatikan tugas tersebut bahkan jarang untuk mengumpulkan tugas

\section{Kosentrasi Belajar}

Setiap Siswa mempunyai keterampilan yang berbeda-beda dalam hal belajar, seperti keterampilan membaca,mendengar, dan menulis yang mereka peroleh dari pengalaman belajarnya yang sudah pasti akan berpengaruh dengan prestasi belajar. Siswa hendaknya mampu berkosentrasi saat proses belajar mengajar berlangsung, kosentrasi belajar sangat besar pengaruhnya terhadap belajar. Jika seseorang mengalami kesulitan kosentrasi, jelas belajarnya akan sia-sia, karena hanya membuang tenaga, waktu dan biaya saja. Seseorang dapat belajar dengan baik adalah orang yang dapat berkosentrasi dengan baik, sebagaimana yang diungkapkan oleh pak La Runggasa selaku Guru di Sekolah SMA 1 Gu.

iya, kalau kosentrasi Siswa disini dalam proses belajar mereka memperhatikan, namun ada juga sebagian Siswa yang yang kurang perhatikan" (Senin,08 Februari 2021)

Dari wawancara diatas dapat diketahui bahwa dalam proses belajar kosentrasi Siswa ketika menerima materi dikelas kosentrasi mereka terfokus pada 


\section{WELVAART}

mata pelajaran namun sebagian kecil ada juga Siswa yang kurang memperhatikan mata pelajaran yang bersangkutan.

4. Kemampuan Berprestasi

Kempampuan berprestasi unjuk hasil belajar merupakan puncak suatu proses belajar, Pada tahap ini Siswa membuktikan hasil belajar yang telah lama iya lakukan. Siswa menunjukan bahwa ia telah mampu memecahkan tugas-tugas belajar atau menstranfer hasil belajar, dari pengalaman sehari-hari di Sekolah diketahui bahwa ada sebagian Siswa juga kurang mampu dalam berprestasi. Sebagaimana diungkapkan Ibu Harmin Hatma selaku Guru di Sekolah SMA Negeri 1 Gu Kabupaten Buton Tengah:

Dalam berprestasi sebagian Siswa disini banyak yang berprestasi, bahkan ada juga yang ikut olimpiade lomba cerdas cermat mereka menang, bahkan mengenai mata pelajaran juga pernah mereka mengikutinya, itu Siswa yang rajin, tapi kalau Siswa yang malas tidak pernah, karna bedah toh orang yang benar-benar ingin pintar dan orang yang hanya sekedar ikutikutan.' (Kamis, 11 Februari 2021)

Dari hasil wawancara diatas dapat disimpulkan bahwa tingkat prestasi belajar anak tergantung pada kemampuan yang dimiliki siswa setelah iya menerima pengalaman belajarnya dan kemauan siswa yang bersungguh-sungguh dalam belajar. Kemapuan berprestasi tersebut terpengaruh pada proses-proses penerimaan, pengaktifan, prapengolahan, penyimpanan,serta pemanggilan untuk pebangkitan motivasi dan pengalaman.

\section{Rasa Percaya Diri}

Kepercayaan diri merupakan salah satu unsur kepribadian yang memegang peranan penting bagi kehidupan manusia. Banyak ahli mengakuai bahwa kepercayaan diri merupakan faktor penting penentu kesuksesan seseorang, tidak dapat disangka lagi bahwa untuk mencapai dalam hidup manusia membutuhkan kepercayaan diri, namun permasalahannya banyak orang yang tidak memiliki kepercayaan diri meski pandai secara akademi. Hal ini dikarenakan kepercayaan diri ini bukan sesuatu yang dapat tumbuh dan ada dalam diri seseorang dengan 


\section{WELVAART}

sendirinya. Sebagaimana yang diungkapkan oleh Ibu Wa Saiyah selaku Guru di SMA Negeri 1 Gu Kabupaten Buton Tengah:

Kebanyakan itu siswa disini rasa percaya dirinya siswa ketika ada pertanyaaan yang saya berikan dikelas mengenai materi yang saya berikan kepada mereka untuk menjawab pertanyaan itu mereka malu-malu, meskipun sebenarnya jawaban itu sudah ada dipikiran mereka,sebab rasa percaya diri mereka itu kurang'.( Senin 04 Februari 2021).

Dari hasil wawancara diatas dapat disimpulkan bahwa rasa percaya diri Siswa dikelas ketika menjawab pertanyaan yang diberikan oleh Guru-guru yang mengajar dikelas siswa tidak percaya diri terhadap kemampuan yang mereka miliki untuk menjawab pertanyaan yang diberikan oleh guru. Dengan seperti ini maka seorang guru yang memberikan materi dikelas harus mengubah pola piker siswa agar mereka lebih percaya diri dan mau menunjukan bakat terhadap kemampuan yang mereka miliki.

\section{Faktor Ekternal}

\section{a. Keluarga Broken Home}

Keluarga adalah tempat pertama bagi Anka-anak untuk menempuh pendidikan dan pengetahuan,dalam perkembangan anak membutuhkan perthatian, kasih saying orang tua, keharmonisan dalam keluarga, untuk membentuk sikap dan perilaku anak yang baik. Berikut penuturan saat proses wawancara dengan Pak La Huri selaku Guru BK di sekolah SMA Negeri $1 \mathrm{Gu}$ Kabupaten Buton Tengah:

kebanyakan penyebab kenakalan yang anak-anak lakukan karena memiliki masalah dalam keluarga mereka, seperti kurangnya perhatian dan kasih saying dari orang tua Siswa dan kebanyakan orang tua Siswa yang ada di Sekolah SMA Negeri $1 \mathrm{Gu}$ Kabupaten Buton Tengah ini orang tua mereka broken home.' (Senin, 14 Februari 2021)

Dari hasil wawancara diatas dapat diketahui bahwa kehadiran orang tua dalam perkembangan jiwa anak sangatlah penting, pengalaman buruk dalam keluarga akan buruk pula diperhatikan terhadap lingkungan seperti halnya dalam keluarga yang mengalami broken home, peran orang tua dalam mendidik anak akan tertangguh dalam pola pengasuhannya. 


\section{WELVAART}

\section{b. Rendahnya Tingkat Pendidikan Orang Tua}

Keberhasilan penddikan seorang anak terutama dalam menyangkut pencapaian prestasi belajar yang baik,dipengaruhi oleh beberapa faktor yang salah satunya adalah bagaimana cara orang tua mengarahkan cara belajar anaknya. Berikut penuturan saat proses wawancara dengan Pak La Huri selaku Guru BK yang ada di Sekolah SMA Negeri 1 Gu Kabupaten Buton Tengah yaitu:

selain itu penceraian dari orang tua siswa, kebanyakan juga rendahnya prestasi belajar anak karena disebabkan tingkat pendidikan orang tua siswa itu sangat rendah, mereka kurang memperhatikan anak-anakknya.'’( Kamis 18 Februari 2021)

Berdasarkan hasil wawancara diatas dapat disimpulkan bahwa, orang tua Siswa yang ada di Sekolah SMA Negeri 1 Gu Kabupaten Buton Tengah, tingkat pendidikan orang tua Siswa sangat rendah sehingga kurang memperdulikan tingkat belajar dan prestasi anak-anaknya baik di Sekolah maupun dirumah. Sementara tingkat penddikan seseorang akan berpengaruh terhadap kematangan emosional, pengetahuan dan sikap yang dimiliki orang tua itu untuk memberikan contoh yang baik kepada anak-anaknya.

c. Lingkungan Sosial

Penyebab kenakalan yang anak lakukan di Sekolah ini bukan hanya disebkan faktor dari keluarga broken home, rendahnya tingkat penddikan orang tua saja, tetapi ada juga karena faktor lingkungan dimana tempat mereka tinggal. Lingkungan Sosial memegang peranan besar terhadap munculnya corak dan gambaran kepribadian pada anak. Sebagaimana ungkapan Pak La Huri selaku Guru BK yang ada di Sekolah SMA Negeri $1 \mathrm{Gu}$.

"penyebab kenakalan yang terjadi di Sekolah ini dipengaruhi juga oleh faktor lingkungan, karena lingkungan disini adalah lingkungan peminum, dan kebanyakan juga siswa-siswinya disini berada ruang lingkup mereka hanya berada diruang lingkup yang tidak baik, sehingga gaya bicara mereka dan perilaku mereka terkontaminasi dengan kaya lingkungan mereka dimana berada sehingga menyebabkan salah bergaul.'’( Jumat 20 Februari 2021)

Berdasarkan ungkapan diatas bahwa lingkungan yang tidak baik pun sangat berpengaruh terhadap tumbuh kembang anak, dan seorang anak pun harus lebih 


\section{WELVAART}

JURNAL ILMU KESEJAHTERAAN SOSIAL

http://ojs.uho.ac.id/index.php/WELVAART

diperhatikan dalam bergaulnya, sebab terkadang mereka salah bergaul dan lebih tertarik pada kelompok teman ketimbang orang tuanya.

\section{Bentuk Intervensi Guru Bimbingan Konseling Dalam menangani Siswa Bermasalah}

a. Konseling Individu

Bentuk Konseling individu ini dalam upaya pemberian bantuan yang diberikan secara individu dan langsung bertatap muka atau pemberian bantuan secara face to face antara Guru BK dengan siswa yang bermasalah yang dilakukan dengan proses wawancara antara Guru BK dengan siswa. Sebagaimana ungkapan Pak La Huri selaku Guru BK yang ada di SMA Negeri $1 \mathrm{Gu}$

layanan Konseling individu itu dilakukan apabila ada Siswa yang bermasalah mereka datang melapor ama saya atau saya yang datang menghampiri Siswa,kenapa saya pergi menghampiri mereka karena mereka lari-larikan saya (Guru BK),kemudian konseling individu dilakukan antara saya (Guru BK) dengan siswa yang bermasalah yang dihadapi siswa untuk memberikan penjelasan kepada saya mengenai masalah apa yang siswa lakukan, biasanya pada awalnya siswa sulit untuk mengungkapkan masalahnya namun dengan secara perlahan saya mencoba untuk mengenali masalah siswa dengan perlahanlahan, setelah mendapat penjelasan dari masalah siswa yang ia lakukan kemudia saya menyurati orang siswa.' ( Rabu 24 Februari 2021)

Berdasarkan hasil wawancara diatas dapat diketahui bahwa Bentuk Intervensi Guru Bimbingan Konseling yang diberikan kepada siswa yang bermasalah di Sekolah SMA Negeri 1 Gu Kabupaten Buton Tengah dengan menggunakan konseling individu,dimana ketika ada siswa yang bermasalah biasanya siswa mengadukan kepada Guru BK mengenai masalahnya atau Guru BK yang mengahampiri siswa yang bermasalah tersebut, kemudian Guru BK melakukan proses wawancara secara of to face dengan siswa yang bermasalah untuk mengetahui permasalahan siswa yang dilakukan biasanya pada awalnya sulit untuk mengungkapkan kesalahan yang mereka lakukan.

b. Konseling Kelompok

Konseling kelompok merupakan upaya bantuan kepada siswa dalam rangka pemberian kemudahan dalam pengembangan dan pertumbuhan secara 


\section{WELVAART}

berkelompok. Selain bersifat pencegahan konseling kelompok dapat pula bersifat penyembuhan, Konseling kelompok bersifat pencegahan dalam arti bahwa siswa yang bersangkutan mempunyai kemampuan untuk berfungsi secara wajar, tetapi mungkin memiliki sustau titik lemah dalam kehidupannya sehingga mengganggu kelancaran berkomunikasi dengan orang lain. Konseling kelompok bersifat pemberian kemudahan dalam pertumbuhan dan perkembangan siswa dalam arti bahwa konseling kelompok itu menjanjikan dan memberikan dorongan kepada siswa yang bersangkutan untuk mengubah dirinya selaras dengan minatnya sendiri.

Seorang Guru Bimbingan Konseling harus mampu melihat permasalahan yang dihadapi siswa secara jelas agar dalam pemecahan masalah-masalah yang dihadapinya sesuai dengan solusi yang diberikannya. Sebagaimana ungkapan Pak La Huri selaku Guru BK yang ada di SMA Negeri 1 Gu Kabupaten Buton Tengah.

"dalam bimbingan konseling kelompok yang saya lakukan disini, saya melihat permasalahan siswa yang sama kemudian saya lakukan konseling kelompok diruang kelas, biasanya siswa disini masalahnya mengenai pertemanan, mereka masing-masing punya Geng, dan permasalahannya biasanya itu dari anggota geng yang satu berpindah ke Geng yang lain, karena sudah tidak merasa nyaman digengnya yang dulu itu, namun juga mengenai interaksi siswa dengan siswa lain yang kurang nyambung dalam percakapan antar mereka akhirnya timbul sebuah permusuhan diantara mereka.'(Jumat,26 2021)

Berdasarkan hasil wawancara diatas dapat diketahui bahwa Bentuk Konseling kelompok dalam menyelesaikan masalah yang diberikan oleh Guru Bimbingan Konseling di Sekolah SMA Negeri 1 Gu Kabupaten Buton Tengah, dengan melihat permasalahan siswa yang sama, dapat memudahkan Guru BK dalam penyelesaian masalah siswa, dimana setelah siswa yang bermasalah dikumpulkan dalam suatu ruangan untuk diberikan motivasi dan penyelesaian masalah yang mereka hadapi. Dalam penyelesaian masalah dengan menggunakan konseling kelompok di Sekolah SMA Negeri 1 Gu Kabupaten Buton Tengah ini sangat baik, karena siswa cepat merespon.

c. Bimbingan Kelompok

Bimbingan Kelompok dimaksudkan untuk mencegah berkembangnya masalah atau kesulitan pada diri Siswa. Isi kegiatan bimbingan kelompok terdiri 


\section{WELVAART}

atas penyampaian informasi yang berkenaan dengan masalah penddikan, pekerjaan,pribadi, dan masalah social yang tidak disajikan dalam dalam bentuk pembelajaran.

Namun di Sekolah SMA Negeri 1 Gu Kabupaten Buton Tengah ini Guru Bimbingan dan Konseling tidak menggunakan bimbingan kelompok, Guru BK hanya fokus pada kedua bentuk Intervensi dalam menyelesaikan permasalahan siswa yang mereka hadapi yaitu dengan konseling individu dan konseling kelompok. Menurut Guru BK dengan kedua Bentuk ini sudah baik dalam menangani siswa yang bermasalah. Berikut ungkapan Pak La Huri selaku Guru BK:

disini saya tidak melakukan bimbingan kelompok kepada siswa yang bermasalah, karena saya lihat bahwa dengan dengan konseling individu dan konseling kelompok, saya bisa mengungkap masalah-masalah yang dihadapi siswa, dan saya rasa denga kedua bentuk itu sudah efektif dalam memecahkan masalah siswa.'’(Sabtu,27 2021)

Berdasarkan hasil wawancara diatas dapat diketahui bahwa dengan menggunakan konseling individu dan konseling kelompok dalam memecahkan masalah siswa di Sekolah SMA Negeri 1 Gu Kabupaten Buton Tengah ini yang digunakan oleh Guru BK sudah dianggap efektif.

d. Keberfungsian Sosial Siswa

Keberfungsian Sosial secara sederhana dapat didefinisikan sebagai kemampuan seseorang dalam melaksanakan fungsi sosialnya dan tugas-tugas kehidupannya sesuai dengan status soialnya. Berdarsarkan Bentuk Intervensi Guru Bimbingan dan Konseling dalam menangani siswa bermasalah dengan menggunakan konseling kelompok dan konseling individu, keberfungsian sosial siswa yang bermasalah sudah berfungsi social dengan baik.

\section{KESIMPULAN}

Faktor yang menyebabkan siswa yang bermasalah di Sekolah SMA Negeri $1 \mathrm{Gu}$ Kabupaten Buton Tengah adalah faktor internal dan faktor eksternal. Dimana faktor internal terdiri dari (1) sikap terhadap belajar siswa yang dimana ketika 


\section{WELVAART}

berada diruangan kelas disaat mereka menerima mata pelajaran sikap mereka kurang terkontrol dan kurang beretika t.(2) motivasi belajar, dimana motifasi belajar siswa terutama dalam membaca buku sangat minim, dan mereka sangat jarang mengerjakan tugas rumah (PR) yang diberikan oleh Guru mata pelajaran yang bersangkutan.(3) kosentrasi belajar, dalam proses belajar kosentrasi siswa terhadap mata pelajaran yang diterima sebagian besar siswa memperhatikan mata pelajaran dan sebagian kecil juga siswa kurang memperhatikan mata pelajaran yang diberikan oleh Guru yang bersangkutan. (4) kemampuan berprestasi, sebagian besar siswa di Sekolah SMA Negeri 1 Gu Kabupaten Buton Tengah, sebagin besar mampu berprestasi namun sebagian kecil juga tidak mampu berprestasi.(5) rasa percaya diri siswa yang ada di sekolah SMA Negeri 1 Gu Kabupaten Buton Tengah, sangat menim terutama dalam menjawab pertanyaan yang diberikan oleh Guru mata pelajaran yang bersangkutan.faktor yang kedua adalah faktor eksternal,dimana faktor, eksternal terdiri dari (1) keluarga broken home, kebanyakan dari siswa yang bermasalah disebkan oleh kedaan keluarga yang sudah tidak harmonis lagi, yang dimana siswa tersebut masih membutuhkan kasih sayang dan perhatian darikedua orang tuanya,(2) rendahnya tingkat pendidikan orang tua, dalam keberhasilan pendidikan seorang anak terutama terutama dalam pencapaian prestasi belajar yang baik dipengaruhi oleh bagaimana cara orang tua mengarahkan cara belajar anak yang baik, namun pendidikan orang tua siswa yang ada di sekolah SMA Negeri 1 Gu Kabupaten Buton Tengah sangat minim sehingga mereka tidak memperhatikan prestasi belajar anaknya karena akibat dari ketidak tahuan mereka terhadap mendidikan.(3) Lingkungan Sosial, akan memegang peranan besar terhadap munculnya corak dan gambar kepribadian pada anak, seprti halnya siswa yang ada di Sekolah SMA Negri 1 Gu Kabupaten Buton Tengah. Lingkungan Sosial tempat tinggal mereka kurang baik, dengan lingkungan Sosial yang tidak baik dapat mempengaruhi sikap dan perilaku anak.

Bentuk Intervensi Guru Bimbingan dan Konseling dalam menangani Siswa yang bermasalah. Di Sekolah SMA Negeri 1 Gu Kabupaten Buton Tengah adalah dengan melakukan konseling individu dan konseling kelompok. Dimana 


\section{WELVAART}

Konselingindividu dilakukan ketika ada siswa yang bermasalah mereka mengaduka ke Guru BK atau guru bimbingan konseling yang mengahanpiri siswa yang bermasalah, setelah siswa berada diruangan Guru BK maka Guru BK melakukan wawancara dengan siswa tersebut untuk mengetahui permasalahan yang siswa lakukan, jika permasalahan siswa yang dilakukan berat maka Guru BK menyurati kedua orang tuanya, dan apabila orang tua siswa tidak datang dalam panggilan tersebut maka siswa yang bermasalah tidak diizinkan untuk masuk sekolah, apalagi mengikuti mata pelajaran yang bersangkutan. Sedangkan konseling kelompok yang dilakukan oleh guru bimbingan kelompok dalam penyelesaian masalah,diamana guru BK melihat permasalahan siswa yang sama,kemudian dikumpulkan dalam satu ruangan untuk menyelesaikan permasalahan yang mereka hadapi dengan pemberian motifasi terhadap siswa.

\section{DAFTAR PUSTAKA}

Alwi F, S 2018. Proses Kominukasi Guru Bimbingan Konseling dalam Proses Belajar (Studi Kasus SMA Muhammadiyah 2 Yogyakarta). Vol 2 No. 2 Universitas Muhammdaiyah Yogyakarta, Yogyakarta.

Irwansa. A. 2015. Analisis Pelaksanaan Tata Tertib Sekolah Pada Siswa di SMK. Negeri 1 Makassar. Universitas Negeri Makassar, Makassar.

Prayitno dan Erman Amti. 2014. Dasar-dasar Bimbingan Konseling. Jakarta PT.Rineka Cipta

Undang-undang sisdiknas No.20 tahun 2003 tentang sytem pendidikan.

Upe, Ambo. 2016. Metode Penelitian Sosial (Filosofi dan Desain Praktis). Kendari . Literacy Institute. 